\begin{tabular}{cc|} 
Journal of Association of Arab Universities \\
for Tourism and Hospitality (JAAUTH) \\
Vol. 20 No. 1, (2021), pp.27-36. \\
journal homepage: http://jaauth.journals.ekb.eg
\end{tabular}

\title{
Using Rumours and Dark Stories to Promote Tourism: Applied to Egyptian dark tourism sites
}

\section{Shaimaa Mohamed Nagib, Ghada Hammoud, Hosam Refai, and Manal Hammad}

Museums and Heritage management, Helwan University, Faculty of Tourism and Hotel Management, Cairo, Egypt.

\section{ARTICLE INFO \\ Keywords: \\ Dark Stories; \\ Marketing; \\ Rumours; \\ Interpretation; Dark Heritage Sites.}

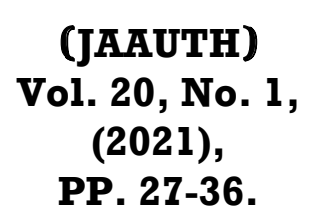

\begin{abstract}
As known, tourism bears an exceptional ability to generate profit and furnish job opportunities, besides finding methods on how to gain benefits of dark tourism to the growth of the Egyptian tourism sector. So the study focuses on how to use a unique set of marketing tools as Rumours and Dark testimonies to entice visitors to go to visits darkish heritage sites which using uncommon scenarios and it's primarily based on the technique of the interpretation that affords to the site visitors as a unique experience it combines the tangible and intangible effects inside the sites. Also, the study draws attention to unfamiliar types of tourism through using technology, exhibitions, drama and storytelling. The study also investigates how the community can cooperate with the stakeholders in promoting dark tourism with stakeholders for implementation. Finally, the research approach is based totally on a descriptive-analytical study, using the method of descriptive analysis resources like empirical and theoretical articles, journals, newspapers, websites, books, blogs and using an online survey.
\end{abstract}

\section{Introduction}

Nowadays, numerous dark locales draw in millions of visitors from all around the world: Auschwitz-Birkenau, Anne Frank's House, Graceland, Oklahoma City, Gettysburg, Vimy Ridge, the Somme, Arlington National Cemetery and creation of an apartheid museum in Johannesburg, South Africa, the list grows each year Due to the increasing popularity of this tourism product, because of that a few academics have studied the phenomenon. Leading the fields are Lennon and Foley, who labelled it Dark Tourism, Seaton who coined the term Thana tourism, and Rojek who developed the concept of Black Spot (Tarlow, 2007). It's the phenomenon that offers a (re)presentation of death and human suffering. As a result, this is identifying dark tourism as visitations to places where tragedies or historically noteworthy death has 
occurred and that continue to impact our lives. Dark tourism is a relatively new area of research and many aspects still require further investigation. Hence, the literature continues to be eclectic, theoretically fragile and thus inconclusive (Stone, 2011).

\section{Literature review}

Sites associated with awful or myth events are gaining more popularity around the world. Moreover, these destinations empower individuals to live a unique, impactful experience (Brina et al., 2013). As a sequence, motivating factors can be the reason for exploring the unknown or educational purposes (Stupart, 2013). The main Dark Heritage management criteria in creating attractiveness for tourists while preserving authenticity includes both - tangible and intangible heritage (Miles, 2014). Otherwise, visitors to the Dark Heritage sites not only satisfy their curiosity, but they also need to get an authentic experience, which could be transmitted by interpreting the place and context related to human (Podoshen, 2013). Moreover, the motivations beyond the visit to dark sites as:

- The search for novelty, identity, horror, nostalgia, the pursuit of knowledge, the feeling of social responsibility and empathy (Brochu and Merriman, 2008).

- Interest in mortality and heritage, violence and suffering, curiosity, adventure and self-understanding (Chapman et al., 2011).

- The famous tourist attractions related to death, the general interest in the sites of death, the desire to sight the actual site and sympathy with the victims (Ryan and Cave, 2007).

- Sentimental experience to relate individuals to their heritage (Yuill, 2004).

Dim locales areas worldwide:

Dark stories associated with tourism destinations are scattered worldwide (Fonseca et al., 2015), some of these are recorded beneath:

- Detained and annihilation encampment at Auschwitz (Poland).

- Ground Zero-The Patriotic Memorial, September $11^{\text {th }}$ (United State).

- Dow Hill located in Kurseong (India).

- Hiroshima Peace Monumental garden (Japan).

- Dracula Citadel- Bran Fort (Romania).

- The Isle of the Dummies (Mexico).

- Jack The Hoodlum (London).

- Kuldhara (India).

\section{Rumours and Dark Stories as a marketing tool}

Dark heritage is an expression gotten from Dark tourism, what's more, a shape of tourism, where they visit sites that are related to death and calamity (Heisel et al., 2013). It's not a recent phenomenon that people travel to places that are allied with death. In fact, individuals have always been smitten with doom, violence and accidents. Dark heritage covers objects, rituals and sites itself, which can be tactile or immaterial, for example, the graves are a dark heritage site, the ritual of inhumation is intangible (Burns and Novelli, 2008). Dark heritage by its definition is not necessarily 
dark, but there is a strong rapport between death and anguish. Dark heritage is integrated with dark tourism in locations like museums or exhibitions that hold no relation to the dark place, but have a showcase of objects or stories about death and tragedy, so the stories, objects and themes are a dark heritage (Mowatt and Charles, 2011). For example, one must think of holocaust museums or exhibitions about slavery and former concentration camps, so, the primary trip of dark tourism with a guide took place in the 1960s, where persons could book an organized train trip to witness the hanging of two murderers (Best, 2007). In the 19th century, it was common to visit the morgue, for that the forerunner of the Body worlds exhibition, which attracts thousands of visitors worldwide (Stupart, 2013). Hence, by taking sight in Egyptian dark tourism sites, it has many historical sites that require efficient development, management, interpretation and promotion as darkish tourism sites. Egypt has abundant dark stories which related to various Heritage sites as the Baron and Sakakini palace that shows the power of Rumours and the Myths that are surrounding the Egyptian civilization in diverse ages and historical sites.

\section{The power of interpretation}

Storytelling is a powerful tool to attract new visitors. Interpretation is considered a significant element in the administration and presentation of places of death and suffering, thus, interpreting dark sites for multiple audiences so important with focusing on how to involve visitors emotionally with dark sites. (Slade, 2003). Also, visitors can meditate the dark sites in plenty of ways, it depends on their own experiences and positions, but the best thing to do is to be engaged, and they have to share stories and to communicate (Isaac et al., 2014).

\section{Steps needed for implementation:}

Egypt has several dark Historical sites that require efficient promotion due to using the Dark Stories, Rumours and Myths related to different Heritage sites in Egypt as Baron and Sakakini palace and many other which need creativity to implement Dark tours for visitors uniquely. Thus, it will be there several dark tourism destinations to discover in your next adventure. Besides, there are main steps that need to be considered when implementing dark tourism in Egypt:

1. Raising awareness of Dark sites in Egypt because they are still an obscure concept. It is valuable to include the Dark sites on the Egyptian tourist map. In order to, contribute to the diversification of the demand for the Egyptian tourism product that is using Rumours, Dark Stories and Mysteries as applications for the Dark sites.

2. Exhibiting artefacts relating to the tragedy in Museums.

3. Offering tourist brochures of Dark sites.

4. Selling souvenirs in Dark sites to serve as reminders of the trip.

5. The close collaboration of partnerships, networking and interdisciplinary to improve the tourism market.

6. Using technology and Visual Media can bring Dark sites to public consciousness, creating destination awareness for potential visitors (Bird and Thiesen, 2018). For example, the Titanic film onto the big screen in 1998. 
7. Including special events related to the Dark Heritage in the Tourism sector.

\section{Dark heritage sites in Egypt}

Egypt has several destinations which considered major dark attraction sites such as battles and wars sites, soldiers and celebrities tombs, memorials, leaders homes, places of killing and assassinations, cemeteries, mausoleums and others (Attia et al., 2015). Thus, It needs promoting as dark sites through re-using, storytelling and interpretation, (see table, 1).

\section{Table 1}

Some sorts of Dark tourism and their sites in Egypt:

\begin{tabular}{|c|c|c|}
\hline A Sort of Dark Tourism & Province & Sites \\
\hline \multirow[t]{4}{*}{ 1- Horror Tourism } & Cairo & $\begin{array}{l}\text { - Baron and Al Sakakini Palace, Zuwayla } \\
\text { door. }\end{array}$ \\
\hline & Alexandria & - Re-simulation of RIA and Sekeena stories. \\
\hline & Luxor & - Re-simulation of the Pharos curse Myth. \\
\hline & $\begin{array}{c}\text { South of } \\
\text { Sinai }\end{array}$ & - Mount Al Banat in Saint Catherine. \\
\hline \multirow[t]{9}{*}{ 2- War Tourism } & Cairo & $\begin{array}{l}\text { - October War`s Panorama, Castle of Babylon, } \\
\text { Military Museum in Salah al-Din Castle. }\end{array}$ \\
\hline & $\begin{array}{l}\text { Alexandria } \\
\text { Northern } \\
\text { Sinai }\end{array}$ & $\begin{array}{l}\text { - El-Sadat Museum at Biblioteca Alexandrina. } \\
\text { - Military Museum, Horus route, El-Arish } \\
\text { Castle, Tina Castle, Castle of Tel Kawthar (A } \\
\text { military shelter of Israeli forces in 1967: } \\
\text { 1973). }\end{array}$ \\
\hline & $\begin{array}{c}\text { Southern } \\
\text { Sinai }\end{array}$ & - Soldier Castle at Ras Sidr \\
\hline & Port Said & - Port Said Military Museum. \\
\hline & Suez & - Metla Path and Suez Museum. \\
\hline & Ismailia & $\begin{array}{l}\text { - Police Museum, Abu Atwa Museum (the } \\
\text { sniper of Tanks), Tree area (martyrdom area } \\
\text { of Abdel Moneim Riad). }\end{array}$ \\
\hline & Matrouh & - Rommel Museum. \\
\hline & Al Alamein & - El Alamein Military Museum. \\
\hline & \begin{tabular}{|l|} 
Luxor \\
\end{tabular} & - Ramesseum and Habu Temples. \\
\hline \multirow[t]{5}{*}{ 3- Grave Tourism } & Cairo & $\begin{array}{l}\text { - Grave of the President Gamal Abdel Nasser } \\
\text { President, Mohamed Anwar Sadat, the leader } \\
\text { Saad Zaghloul. }\end{array}$ \\
\hline & Giza & $\begin{array}{l}\text { - Tomb`s at Giza, Saqqara and Dahshur } \\
\text { Pharaonic Civilization, Pyramids. }\end{array}$ \\
\hline & Alexandria & $\begin{array}{l}\text { - Latin cemetery, The Catacomb and } \\
\text { Commonwealth military graves. }\end{array}$ \\
\hline & Al Alamein & \multirow{2}{*}{$\begin{array}{l}\text { - Commonwealth, German \& Italian graves. } \\
\text { - Mountain of the dead. }\end{array}$} \\
\hline & Siwa & \\
\hline & & Continued \\
\hline
\end{tabular}




\begin{tabular}{|c|c|c|}
\hline & Oases & $\begin{array}{l}\text { - The Valley of the Golden Mummies tomb, } \\
\text { the Pharaoh's tombs at El- Dakhla, Albagauat } \\
\text { cemeteries. }\end{array}$ \\
\hline & Minya & - Tuna El-Gebel, Bani Hassan. \\
\hline & Luxor & - Tombs of the Valley of the Kings \&Queens. \\
\hline & Aswan & $\begin{array}{l}\text { - Tombs of the Nobles, Cape City ruins, Aga- } \\
\text { Khan Shrine, the anonymous Soldier's grave. }\end{array}$ \\
\hline & Suez & - The martyrs' tombs of 6th of October. \\
\hline \multirow[t]{4}{*}{ 4- Forts Tourism } & Alexandria & - Kaitbay Citadel. \\
\hline & Damietta & - Orabi Citadel. \\
\hline & Beheira & $\begin{array}{l}\text { - Orabi castle at Edco, Qaitbay Fort at } \\
\text { Rasheed. }\end{array}$ \\
\hline & Aswan & - Phiela Island. \\
\hline \multirow[t]{4}{*}{ 5- Massacres Tourism } & Cairo & $\begin{array}{l}\text { - Mamluks massacre at the } \mathrm{Bab} \text { El Azab } \\
\text { Route. }\end{array}$ \\
\hline & Menoufia & - Donshway Massacre. \\
\hline & Sharqiya & - Bahr Al Baqar Massacre. \\
\hline & $\begin{array}{c}\text { Northern } \\
\text { Sinai }\end{array}$ & $\begin{array}{l}\text { - Massacres of El Arish, Rafah \& Sheikh } \\
\text { Zuwaid. }\end{array}$ \\
\hline \multirow{5}{*}{$\begin{array}{l}\text { 6- Tourism of Leaders` } \\
\text { Houses/Palaces }\end{array}$} & Cairo & - Gamal Abdel Nasser house. \\
\hline & Alexandria & $\begin{array}{l}\text { - El Montaza Palace, Gamal Abdel Nasser } \\
\text { summer house, Kaffafis Museum, Villa of } \\
\text { Princess Faiza, sister of King Farouk, } \\
\text { Kurdahi Palace, Baron Palace at Menasha, } \\
\text { Antoniades Palace. }\end{array}$ \\
\hline & Giza & $\begin{array}{l}\text { - Revolution Leaders Museum, Gamal Abdel } \\
\text { Nasser and Anwar Sadat Museum. }\end{array}$ \\
\hline & Beheira & - King Farouk Palace at Edfina. \\
\hline & $\begin{array}{l}\text { Ismailia } \\
\text { Sharqiya }\end{array}$ & $\begin{array}{l}\text { - De Lesseps Museum. } \\
\text { - Ahmed Orabi Museum. }\end{array}$ \\
\hline \multirow[t]{5}{*}{ 7- Monument Tourism } & \begin{tabular}{|l|} 
Cairo \\
\end{tabular} & - Unknown Soldier Memorial. \\
\hline & Alexandria & - Naval forces Memorial. \\
\hline & Ismailia & $\begin{array}{l}\text { - 6th of October victory Memorial of the } \\
\text { Armed Forces. }\end{array}$ \\
\hline & \begin{tabular}{|c|} 
Suez \\
\end{tabular} & - October memorial martyrs. \\
\hline & Al Alamein & - Military Museum of Al Alamein. \\
\hline \multirow[t]{2}{*}{$\begin{array}{l}\text { 8- Assassinations } \\
\text { Tourism }\end{array}$} & Cairo & $\begin{array}{l}\text { - The platform of President Anwar El Sadat } \\
\text { assassination. }\end{array}$ \\
\hline & Menoufia & $\begin{array}{l}\text { - El-Sadat Museum of Dar ElSalaam at Mitt } \\
\text { Abo El-Kom. }\end{array}$ \\
\hline $\begin{array}{l}\text { 9- Disasters/Calamities } \\
\text { Tourism }\end{array}$ & $\begin{array}{l}\text { Northern } \\
\text { Sinai }\end{array}$ & - Rain Streams ruins at Ras Sidr, 2010. \\
\hline
\end{tabular}




\section{Dark Tourism Marketing}

The place or destination is not the only product in dark tourism marketing instead of the enriched past of which the locale is the main attraction. Thus, the marketer should try to provide an enriched experience to the tourists due to the product is the destination itself or experience of place (location and people) at a particular time (Laing and Frost, 2016). Yet, the purpose of tourism marketing is to create a unique image of the tourism destination in the minds of tourists to select the destination for their next holiday. Dark Tourism becomes nowadays a thriving phenomenon many countries are trying hard to promote because it is a unique product market.

\section{Methods and Results}

Due to the dearth of studies that dealt with the type of dark tourism, an online survey was designed through a set of questions related to dark tourism to measure the knowledge of visitors and specialists about this type of tourism, which was during brainstorming sessions with a group of specialists and academics. Moreover, a sample of clients held surveyed in places related to Dark tourism, as Baron Palace and Salah El-Din Citadel. Furthermore, it contains the SWOT analysis of the dark tourism market in Egyp which shows whether the audience wants to be a part of the implementation and what obstacles may face dark tourism in Egypt. Indeed, the results were analysed from the response of 122 people out of 300 , of different categories, and the most interested group was that of graduates forming about $38 \%$, followed by university scholars about $38.5 \%$, the employees about $18.9 \%$ and school pupils about 10.7\%. Most participants were looking for an adventure forming about 54.3\%, entertainment about $43.4 \%$ and learning about $23.3 \%$. There is about $51 \%$ of the participants who know about this type of tourism. There is a high percentage of participants who wants to discover and take part in dark tourism forming 58.2\%. Furthermore, Dark Tourism might face obstacles in implementation despite it being attractive to many people. In the end, dark tourism needs a combination of cooperation between society, stakeholders, the security situation and societal culture to be implemented and set on the Egyptian tourism map. the aim of this analysis is to find out what the level of knowledge about Dark Tourism and its sites is. The attraction toward Dark tourism has increased, but it does not exist as a separate type of tourism because the development of dark tourism is surrounded by concerns from heritage professionals that it could have negative perceptions about the acceptability. Indeed, to develop dark tourism, enhancing the knowledge of stakeholders about the importance of Dark Tourism should be involved.

\section{SWOT Analysis of the Egyptian Dark Tourism Market:}

Analyses the strengths, weaknesses, opportunities, and threats of marketing for the cultural heritage of tourism in Egypt; to develop Dark Heritage sites and compete with other destinations in the electronic and traditional market (Salman et al., 2017), yet, following steps should be taken into considerations to fulfil that goal:

1. Identify objectives and target audiences, marketing segmentation, market demand and competitors, distribution channels.

2. Implement Marketing Strategy and Branding, appealing trip planning, unique activities and networking between stakeholders site management. 
3. Monitoring customer impressions through site visitation and engagement measurement, the return on investment, the effectiveness of development and content management and upkeep.

Consequently, it concluded that tourist sites in Egypt have many points of strengths as well as weaknesses that underlined at the following SWOT analysis of, (see table, 2):

Table 2

SWOT of the Egyptian tourism market

\begin{tabular}{|c|c|}
\hline Strengths & Weaknesses \\
\hline $\begin{array}{l}\text { - Diversity of cultural content. } \\
\text { - Easy to access. } \\
\text { - Nearness from services. } \\
\text { - Egyptian heritage includes } \\
\text { mysterious and dark stories. }\end{array}$ & $\begin{array}{l}\text { - Lack of proper coordination between } \\
\text { stakeholder and investors. } \\
\text { - Neglect of some sites, isolation, } \\
\text { destruction and robbed contents. } \\
\text { - The sites are next to crowded suburban } \\
\text { zones and next to military zones. }\end{array}$ \\
\hline Opportunities & Threats \\
\hline $\begin{array}{l}\text { - Auxiliary new tourism activities attract a } \\
\text { new segment of visitors by using unique } \\
\text { presentation tools such as darkish stories } \\
\text { and legends related to heritage sites. } \\
\text { - More available opportunities to finance for } \\
\text { reuse in multiple activities and association } \\
\text { with international and local events. } \\
\text { - Reformation of human skills and quality of } \\
\text { services. }\end{array}$ & $\begin{array}{l}\text { - Lack of proper coordination between the } \\
\text { Local Authorities and the stakeholders } \\
\text { providing tourism-related services. } \\
\text { - Terrorism and damage. } \\
\text { - Inaccessible Historical sites. } \\
\text { - Lack of qualified services. }\end{array}$ \\
\hline
\end{tabular}

\section{The Study Recommends:}

1. Focus on diversifying tourism products to open new markets, attract tourists and increase the ability to competed globally.

2. Reuse the tourism sites because it has tragic stories in creatively.

3. Merge the effort of the public and private sectors to improve the tourism sector.

4. The tourism sector should create unusual solutions and activities to apply in tourism sites instead of using Rumours and Dark stories to interpret heritage sites.

5. Exchange Dark culture with other countries.

6. Improve the ability to competitiveness through adopting new marketing tools like using the drama in marketing Heritage such as (Nasser 56 and Sadat days'), Egyptian tourism needs these ways to attract visitors.

\section{Conclusion}

The vast majority have never heard the term Dark Tourism. Yet, they probably have been to Dark Tourist locales. Indeed, the significance of dark tourism has driven us to introduce many new darkish destinations to compete in tourism markets. 
Consequently, the visitors of darkish sites fulfil their curiosity and get an authentic experience that communicated by interpreting the place and context. In my opinion, Egypt has an assortment of dark tourist attractions, for example, battlefields, graves of military leaders and world-famous people, memorials, leaders homes, places of murder or assassinations, cemeteries and shrines. However, it needs to promote to increase the demand for it by adopting a new tourism marketing tool to contribute to economic development and cooperation between various stakeholders to add the Egyptian, dark sites on the tourism map.

\section{References}

- Attia, A., Abd El-Hady, D. and El-Manhaly, S., 2015. The Role of Dark Tourism in Developing The Demand for The Egyptian Tourist Product. Tourism Research Institute, 12(1), pp.3-14.

- Best, M., 2007. Norfolk Island: Thana-tourism, history and visitor emotions. Shima: The International Journal of Research into Island Cultures, 1(2), pp.30-48.

- Bird, G., Westcott, M. and Thiesen, N., 2018. Marketing dark heritage: Building brands, myth-making and social marketing. In The Palgrave handbook of dark tourism studies (pp. 645-665). Palgrave Macmillan, London.

- Birna, A., Hyde, K.F. and Farmaki, A., 2013. Dark tourism revisited: A supply/demand conceptualisation, International Journal of Culture, tourism and hospitality research.

- Brochu, L. and Merriman, T., 2008. Personal interpretation: Connecting your audience to heritage resources.

- Burns, P.M. and Novelli, M. eds., 2008. Tourism and mobilities: local-global connections. CABI.

- Ch'ng, E., Chapman, H., Gaffney, V., Murgatroyd, P., Gaffney, C. and Neubauer, W., 2011. From sites to landscapes: How computing technology is shaping archaeological practice. Computer, 44(7), pp.40-46.

- Fonseca, A.P., Seabra, C. and Silva, C., 2015. Dark tourism: Concepts, typologies and sites. Journal of Tourism Research \& Hospitality.

- Heisel, A., Clausen, R.F., Michelsen, A.S., Leth, N., Houmann, A. and Skøien, M., 2013. Dark Tourism and the influence of the media. Roskilde University, $\mathrm{HIB}, 3(2)$.

- Isaac, R.K. and Çakmak, E., 2014. Understanding visitors motivation at sites of death and disaster: the case of former transit camp Westerbork, the Netherlands. Current Issues in Tourism, 17(2), pp.164-179.

- Jawabreh, O., 2020. Management of Tourism Crisis in the Middle East. In Publicsector Crisis Management. IntechOpen. 
- Laing, J. and Frost, W., 2016. Dark tourism and dark events: a journey to positive resolution and well-being. In Positive Tourism (pp. 82-99). Routledge.

- Lennon, J.J. and Foley, M., 2000. Dark Tourism: The Attraction of Death and Destruction. London: Cengage Learning EMEA.

- Mackaway, J., 2008. Why do they do it? A case study of National Trust (NSW) volunteers. Australian Journal on Volunteering, 13(2), p.32.

- Miles, S., 2014. Battlefield sites as dark tourism attractions: An analysis of experience. Journal of Heritage Tourism, 9(2), pp.134-147.

- Mowatt, R.A. and Chancellor, C.H., 2011. Visiting death and life: Dark tourism and slave castles. Annals of tourism research, 38(4), pp.1410-1434.

- Podoshen, J.S., 2013. Dark tourism motivations: Simulation, emotional contagion and topographic comparison. Tourism Management, 35, pp.263-271.

- Ryan, C. and Cave, J., 2007. Cambridge Armistice Day celebrations: Making a carnival of war and the reality of play. In Battlefield Tourism (pp. 199-208). Routledge.

- Salman, D., Tawfik, Y., Samy, M. and Artal-Tur, A., 2017. A new marketing mix model to rescue the hospitality industry: Evidence from Egypt after the Arab Spring. Future Business Journal, 3(1), pp.47-69.

- Slade, P., 2003. Gallipoli Thana-tourism: The meaning of ANZAC. Annals of tourism research, 30(4), pp.779-794.

- Stone, P.R., 2011. Dark tourism: Towards a new post-disciplinary research agenda. International Journal of Tourism Anthropology, 1(3-4), pp.318-332.

- Stupart, C., 2013. The development of dark/cultural heritage as attractions in Falmouth, Jamaica, West Indies.

- Tarlow, P.E., 2007. Dark tourism. Niche tourism, 47.

- Tunbridge, J.E. and Ashworth, G.J., 1996. Dissonant heritage: The management of the past as a resource in conflict. John Wiley \& Sons.

- Yuill, S.M., 2004. Dark tourism: understanding visitor motivation at sites of death and disaster (Doctoral dissertation, Texas A\&M University). 


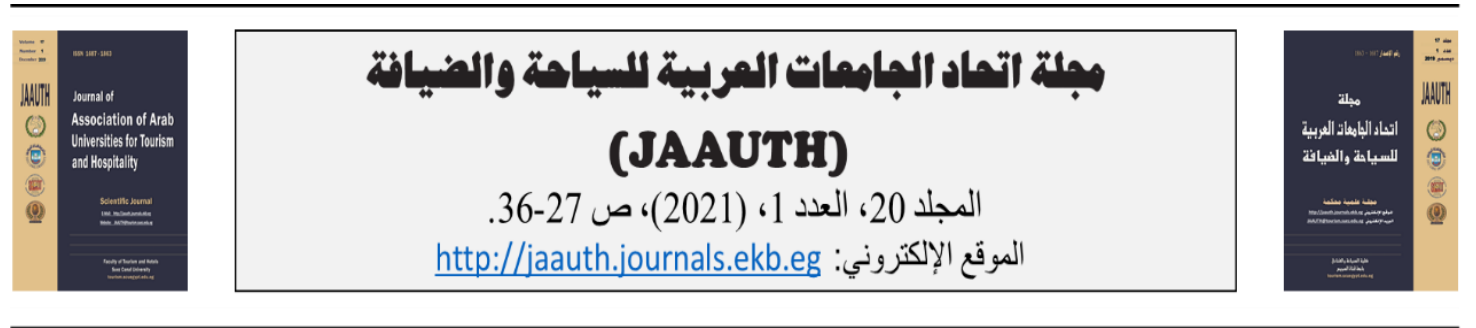

\section{استخام الثائعات والقصص المظلمة للترويج للسياحة}

شيماء محمد نجيب مصطفي، غاده حمود، حسام رفاعي، ومنال برهان

ققم الدراسات المتحفية والتراث، كلية السياحة والفنادق، جامعة حلوان، القاهرة، مصر .

\begin{tabular}{|c|c|}
\hline & \\
\hline 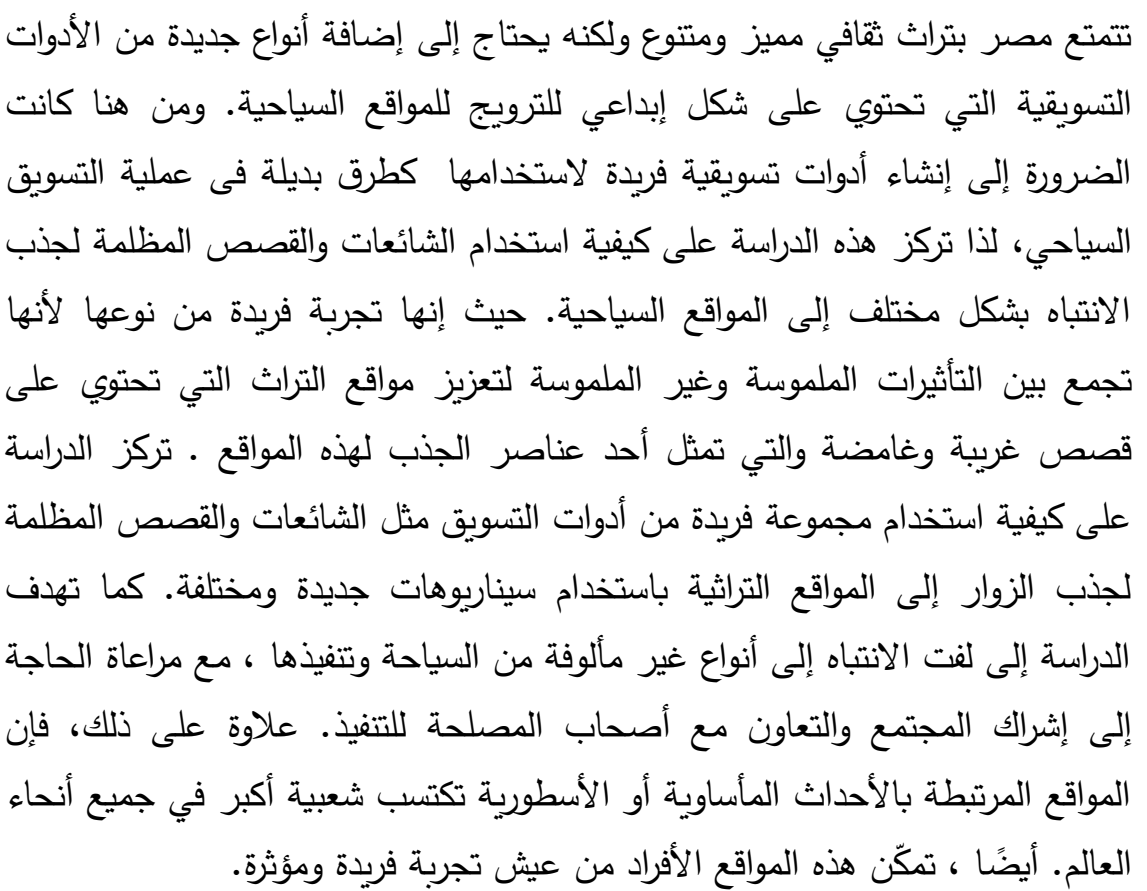 & 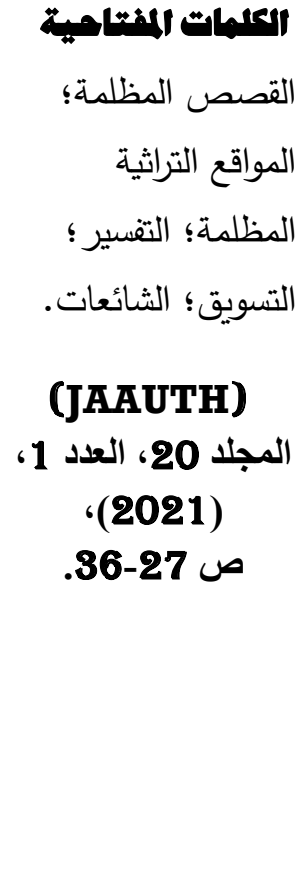 \\
\hline
\end{tabular}

